\title{
Semen Quality Characteristics and Seasonality in Different Varieties of Male Guinea Fowl
}

\section{Jag Mohan ${ }^{1 *}$, Sanjeev Kumar Sharma ${ }^{1}$, Gautham Kolluri ${ }^{1}$, Ram Pratap Singh ${ }^{2}$, Jagbir Singh Tyagi ${ }^{2}$, Jag Mohan Kataria ${ }^{1}$}

\section{${ }^{1}$ Division of Avian Physiology and Reproduction, ICAR-Central Avian Research Institute, Izatnagar - 243 122, Uttar Pradesh, India; ${ }^{2}$ Avian Physiology and Genetics Division, Salim Ali Centre for Ornithology and Natural History, Coimbatore-641108, Tamil Nadu, India.}

\begin{abstract}
Semen characteristics and seasonal reproductive behaviour of male guinea fowl (pearl, lavender and white varieties) were investigated. Thirty healthy (free from any disease/infection) adult male and females from each variety of guinea fowl of same hatch with nearly similar body weight were taken randomly. Semen volume was observed nearly similar in pearl $(0.055 \pm 0.003 \mathrm{ml})$ and lavender $(0.051 \pm 0.003 \mathrm{ml})$ whereas less $(\mathrm{P}<0.05)$ in white variety. No significant difference was observed in sperm motility and live counts among the varieties. Higher number of dead sperm was observed in white variety linked with higher $(\mathrm{P}<0.05)$ number of morphologically abnormal spermatozoa. Sperm concentration was revealed inferior $(\mathrm{P}<0.05)$ in white variety $\left(3.05 \pm 0.17 \times 10^{9}\right.$ cells $\left./ \mathrm{ml}\right)$ with poor fertility $(73.33 \pm 5.15 \%)$ than other varieties. Fertility rates were superior $(\mathrm{P}<0.05)$ using AI technique rather than natural mating. Hatchability was found higher in pearl and lavender than white. In another study, effect of seasonality on testes was investigated. Irrespective of seasons, the left testicular weight was slightly more than right. Testicular weight constitutes 0.23 to 0.28 $\%$ of the total body weight. In all the varieties, nearly 7 to 9 times higher testicular weight was noticed in breeding (long days) than non-breeding (short days) season. Similarly, serum testosterone profile was recorded higher $(\mathrm{P}<0.05)$ in breeding season. Therefore, a positive relationship of testicular weight with testosterone in breeding and non-breeding season was observed. The results of this study would be useful in designing the strategies for breaking the seasonality in guinea fowl so that reproductive efficiency of this bird can be enhanced throughout the year.
\end{abstract}

Keywords | Semen characteristics, Testes, Testosterone, Seasonality, Guinea fowl

Editor | Kuldeep Dhama, Indian Veterinary Research Institute, Uttar Pradesh, India.

Received | May 20, 2016; Accepted | June 07, 2016; Published | June 17, 2016

*Correspondence | Jag Mohan, Principal Scientist and Head, Division of Avian Physiology and Reproduction, ICAR-Central Avian Research Institute, Izatnagar-243122, Uttar Pradesh, India; Email: mohanjagjag@rediffmail.com

Citation | Mohan J, Sharma SK, Kolluri G, Singh RP, Tyagi JS, Kataria JM (2016). Semen quality characteristics and seasonality in different varieties of male Guinea fowl. Adv. Anim. Vet. Sci. 4(6): 320-326.

DOI | Http://dx.doi.org/10.14737/journal.aavs/2016/4.6.320.326

ISSN (Online) | 2307-8316; ISSN (Print) | 2309-3331

Copyright $(92016$ Mohan et al. This is an open access article distributed under the Creative Commons Attribution License, which permits unrestricted use, distribution, and reproduction in any medium, provided the original work is properly cited.

\section{INTRODUCTION}

G uinea fowl is the common name of the seven species

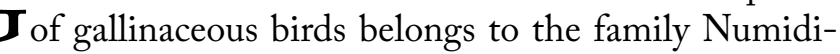
dae, which is native to Africa. Three varieties of guinea fowl are well known such as lavender, pearl and white in which usually females are slightly heavier than male (Nalubama et al., 2014). Guinea fowl meat is rich in protein content (28\%) than that of domestic fowl i.e. 20\% (Ayeni, 1980). These birds have a high dressing percentage (80\%) with excellent meat to bone ratio (Ayeni, 1983). Guinea fowl is comparatively more disease resistant (Bonds, 1997; Mandal et al., 1999; Ikani and Dafwang, 2004) and hardy (Moreki and Seabo, 2012) than chicken. Sayila (2009) observed less mortality (2.2\%) for guinea fowl than chicken (6.8\%). In spite of it, rearing of guinea fowl is not economical due to seasonal egg production and poor fertility associated with hatchability. In addition, the behaviour of guinea fowl is monogamous (Nwagu and Alawa, 1995) which drastically limits its reproductive efficiency when the male counterpart dies. Under these conditions, female will not readily copulate naturally with a new male (Aire et al., 1983; 
Biswas, 1983). Hence, to supply the high quality protein to the growing human population, reproductive efficiency of guinea fowl must be improved by breaking the seasonality and adopting the artificial insemination (AI) in this bird.

Superiority of AI to natural mating has been noticed by Saeki and Nagomi (1964). Further, this technique could be the good alternative to break the inbreeding and monogamous behaviour of male guinea fowl (Aire et al., 1983). The success of AI technique depends on the quality characteristics of semen. Evaluation of semen quality gives an excellent idea of bird's reproductive potential and has been reported to be a major determinant of fertility and subsequent hatchability of eggs (Peters et al., 2004). Considerable information is available on the semen quality of chicken and turkey (Mohapatra et al., 1994; Dimitrov et al., 2007; Zaniboni and Cerolini, 2009; Mohan et al., 2011; Biswas et al., 2014) and frequently used wherever the technique of A.I. is employed. While in guinea fowl scanty literature is available (Nwakalor et al., 1988).

Monogamous and seasonal reproductive behaviour (Nwagu and Alawa, 1995) of guinea fowl has been recognized as one of the major problems that may hinder largescale commercial production of this species. Hence, to enhance the reproductive potential of male bird by seasonality breakdown, adequate research data is required pertaining to the testes during breeding season (BS) and non-breeding season (NBS). Currently, limited information is available on the status of testes and serum testosterone profile during different breeding season of guinea fowl (Ali et al., 2015). With an aim to maximize the production of guinea fowl throughout the year, the present work is designed to establish the semen quality in guinea fowl so that the technique of AI can be executed successfully. Further, preliminary data was collected during BS and NBS on testes and serum testosterone concentration so that appropriate strategy can be planned to break the seasonality in guinea fowl.

\section{MATERIAL AND METHODS}

This study was carried out as per the guidelines of Animal Ethics Committee of ICAR-Central Avian Research Institute, Izatnagar. Under this study thirty adult healthy (free from any disease/infection) males from each variety of guinea fowl (lavender, pearl and white) of the same hatch and nearly similar body weight were taken randomly from the same flock maintained at institute. For fertility studies, same number of adult hens from each variety of the same age were also reared and allowed to get the nor$\mathrm{mal} / \mathrm{breeder}$ ration and water ad libitum with $14 \mathrm{hr}$ light per day. Semen samples were collected during study period by abdominal massage method (Burrows and Quinn, 1935). Semen volume was measured by using micro pipette and sperm concentrations were examined with a Neubauer haemocytometer (Lake, 1960). The percent live and abnormal spermatozoa were counted after preparing smears and staining them with eosin and nigrosin according to the methods described by Lake and Stewart (1978). The sperm motility was assessed by examination of a drop of semen ( 5 $\mu \mathrm{l})$ under the microscope at 10x magnification as described by Wheeler and Andrews (1943). To determine the fertility, hens were inseminated with a 100 million spermatozoa using the Beltsville Poultry Semen Extender-BPSE (Sexton, 1977) diluted semen (1:1). Fertility of male birds was assessed by incubating the eggs layed by hens 2 to 6 days after intravaginal insemination. The percent fertility was determined as the ratio of numbers of fertile eggs to the number of total egg set in the incubator. Hatchability (FES and TES) was calculated as per standard procedure.

Effect of seasonality on testes and testosterone was studied using six birds from each variety and sacrificed by cervical dislocation of the neck in the peak breeding (June-summer long days) and non-breeding (December-winter short days) season. To study the testicular weight, the abdominal cavity was opened and testes were removed carefully from

Table 1: Physical characteristics of semen in different varieties of guinea fowl (means \pm SEM; $n=10$ )

\begin{tabular}{|c|c|c|c|c|c|}
\hline \multicolumn{2}{|l|}{ Parameters } & Units & Pearl & Lavender & White \\
\hline \multicolumn{2}{|l|}{ Semen volume } & $\mathrm{ml}$ & $0.055^{\mathrm{a}} \pm 0.003$ & $0.051^{\mathrm{a}} \pm 0.003$ & $0.035 \pm 0.004^{b}$ \\
\hline \multicolumn{2}{|l|}{ Sperm motility } & $\%$ & $87.00 \pm 4.40$ & $90.11 \pm 3.70$ & $84.34 \pm 5.11$ \\
\hline \multicolumn{2}{|l|}{ Live sperm } & $\%$ & $89.52 \pm 3.97$ & $90.71 \pm 4.11$ & $86.19 \pm 4.91$ \\
\hline \multicolumn{2}{|l|}{ Dead sperm } & $\%$ & $6.04 \pm 0.24$ & $5.21 \pm 0.37$ & $7.02 \pm 0.22$ \\
\hline \multicolumn{2}{|c|}{ Morphological abnormality of sperm } & $\%$ & $4.44^{a} \pm 0.13$ & $4.08^{\mathrm{a}} \pm 0.21$ & $6.79^{b} \pm 0.15$ \\
\hline \multicolumn{2}{|c|}{ Concentration of spermatozoa } & $\mathrm{x} 10^{9}$ cells $/ \mathrm{ml}$ & $3.51^{a} \pm 0.22$ & $3.67^{a} \pm 0.31$ & $3.05^{\mathrm{b}} \pm 0.17$ \\
\hline \multirow[t]{2}{*}{ Fertility } & A.I. & $\%$ & $87.00^{\mathrm{a}} \pm 5.10$ & $84.64^{a} \pm 4.02$ & $73.33^{\mathrm{b}} \pm 5.15$ \\
\hline & N.M. & $\%$ & $55.60 \pm 4.17$ & $56.72 \pm 5.82$ & $52.16 \pm 4.65$ \\
\hline \multirow[t]{2}{*}{ Hatchability* } & FES & $\%$ & 87.35 & 90.58 & 84.93 \\
\hline & TES & $\%$ & 76.00 & 77.00 & 62.00 \\
\hline
\end{tabular}

Means bearing different superscript in a row $(\mathrm{a}, \mathrm{b})$ differs significantly $(\mathrm{P}<0.05)$; *Average of 2 observations; AI: Artificial insemination, NM: Natural mating, FES: Fertile egg set, TES: Total egg set 
surrounding tissues. Body weight was measured by simple weighing balance whereas testicular weight was monitored by employing electronic weighing balance.

Serum was removed by centrifugation at $4000 \mathrm{rpm}$ for 8 min from the blood samples collected from jugular vein of each male bird at 11:00 AM. Testosterone was estimated in serum of all the samples using a commercial ELISA kit (DE1559, Demeditec Diagnostics GmbH, Germany) according to the manufacturer's instruction. The EIA was validated for chicken serum by demonstrating parallelism between serial dilutions of testosterone standard and serum. Data were analysed by using statistical software package SPSS-16 for analysis of variance and Duncan's multiple range tests by comparing means for significant differences at the $5 \%$ level $(\mathrm{P}<0.05)$.

\section{RESULTS}

The mean values of physical characteristics of semen in different varieties of guinea fowl are shown in Table 1 . Semen volume was observed nearly similar in pearl $(0.055 \pm 0.003$ $\mathrm{ml})$ and lavender $(0.051 \pm 0.003 \mathrm{ml})$ whereas less $(\mathrm{P}<0.05)$ in white variety $(0.035 \pm 0.004)$. No significant difference was observed in sperm motility and live count among the three varieties of guinea fowl. Higher number of dead sperm in white variety was associated with higher $(\mathrm{P}<0.05)$ number of abnormal spermatozoa. Sperm concentration was found inferior $(\mathrm{P}<0.05)$ in white $\left(3.05 \pm 0.17 \times 10^{9} / \mathrm{ml}\right)$ with poor fertility $(73.33 \pm 5.15 \%)$ than other varieties of guinea fowl. In all the varieties, fertility rates were noticed higher with AI technique than natural mating. Hatchability was found superior in pearl and lavender than white.
Data pertaining to the relationship of body weight with testicular weight in breeding and non-breeding season in different verities of guinea fowl is given in Table 2. A higher body weight was found in breeding season in all the three varieties of guinea fowl (white, pearl and lavender). However, no significant difference was found among the different varieties in any season. Irrespective of seasons, the left testicular weight was found slightly higher than right. Testicular weight in relation to percent body weight was recorded several fold higher $(\mathrm{P}<0.05)$ in BS. Data indicated a positive relationship of testicular weight with testosterone during both the seasons in all guinea fowl varieties (Table 3). Nearly 7 to 9 times increase in testicular weight were noticed in BS. Similarly, in all the varieties, serum testosterone profile was recorded higher $(\mathrm{P}<0.05)$ in BS than NBS.

\section{DISCUSSION}

Semen volume was found to be $0.035 \pm 0.004 \mathrm{ml}$ in white variety of guinea fowl. This is in agreement with the work carried out by Nwakalor et al. (1988) as they have reported $0.032 \pm 0.001 \mathrm{ml}$. Pal et al. (1999) noticed semen volume for guinea fowl as $0.073 \pm 0.003 \mathrm{ml}$. In our study, the volume of pearl and lavender semen is $0.055 \pm 0.003$ and $0.051 \pm 0.003$ $\mathrm{ml}$ respectively which is nearly $50 \%$ higher than white variety of guinea fowl. This may be due to variation in variety. No significant difference was found in sperm motility and live counts among the three varieties of guinea fowl. Nwakalor et al. (1988) examined the live counts averaged $91.60 \%$ with a range of $87-96 \%$ in guinea fowl whereas, in this study we have noticed $89.52 \pm 3.97,90.71 \pm 4.11$ and $86.19 \pm 4.91 \%$ in pearl, lavender and white variety.

Table 2: Relationship of body and testicular weight in breeding and non-breeding season in different varieties of guinea fowl (mean \pm SEM; $\mathrm{n}=6$ )

\begin{tabular}{|c|c|c|c|c|c|c|c|c|}
\hline \multirow[t]{3}{*}{$\begin{array}{l}\text { Guinea fowl } \\
\text { variety }\end{array}$} & \multicolumn{2}{|c|}{ Body weight (g) } & \multicolumn{4}{|c|}{ Testis weight (g) } & \multicolumn{2}{|c|}{$\begin{array}{l}\text { Testicular weight in } \\
\text { relation to \% body weight }\end{array}$} \\
\hline & \multirow[t]{2}{*}{ NBS } & \multirow[t]{2}{*}{ BS } & \multicolumn{2}{|l|}{ NBS } & \multicolumn{2}{|l|}{ BS } & \multirow[t]{2}{*}{ NBS } & \multirow[t]{2}{*}{ BS } \\
\hline & & & Right & Left & Right & Left & & \\
\hline White & $1500 \pm 24.39$ & $1636 \pm 55.72$ & $0.22 \pm .06$ & $0.28 \pm 0.04$ & $1.76 \pm 0.08$ & $1.98 \pm 0.10$ & $0.033^{\mathrm{a}}$ & $0.23^{b}$ \\
\hline Pearl & $1600 \pm 31.78$ & $1707 \pm 38.86$ & $0.24 \pm .04$ & $0.29 \pm 0.04$ & $2.32 \pm 0.15$ & $2.53 \pm 0.17$ & $0.034^{a}$ & $0.28^{b}$ \\
\hline Lavender & $1592 \pm 36.24$ & $1695 \pm 56.82$ & $0.25 \pm .03$ & $0.34 \pm 0.05$ & $2.02 \pm 0.19$ & $2.71 \pm 0.14$ & $0.037^{a}$ & $0.28^{b}$ \\
\hline
\end{tabular}

Means bearing different superscript in a row $(\mathrm{a}, \mathrm{b})$ differs significantly $(\mathrm{P}<0.05)$; NBS: Non breeding season; BS: Breeding Season

Table 3: Relationship of testicular weight with serum testosterone profile in breeding and non-breeding season in different varieties of guinea fowl (means \pm SEM; $n=6$ )

\begin{tabular}{lllllll}
$\begin{array}{l}\text { Guinea fowl } \\
\text { variety }\end{array}$ & \multicolumn{2}{l}{ Both testis weight $(\mathbf{g})$} & \multicolumn{4}{l}{ Testosterone(ng/ml) } \\
White & NBS & BS & NBS/BS & NBS & BS & NBS/BS \\
Pearl & $0.50^{\mathrm{a}} \pm 0.10$ & $3.74^{\mathrm{b}} \pm 0.18$ & 7.49 & $0.66^{\mathrm{a}} \pm 0.06$ & $2.40^{\mathrm{b}} \pm 0.11$ & 3.64 \\
Lavender & $0.53^{\mathrm{a}} \pm 0.08$ & $4.85^{\mathrm{b}} \pm 0.32$ & 9.15 & $0.58^{\mathrm{a}} \pm 0.08$ & $2.37^{\mathrm{b}} \pm 0.09$ & 4.08 \\
\hline
\end{tabular}

Means bearing different superscript in a row $(\mathrm{a}, \mathrm{b})$ differs significantly $(\mathrm{P}<0.05)$; NBS: Non breeding season; BS: Breeding Season 
Dead sperm ranged from 5 to $7 \%$ in this study whereas, Nwakalor et al. (1988) found slightly higher values (8.4 $\pm 0.1 \%)$. Sperm concentration was ranging between $3.05 \pm 0.17$ to $3.67 \pm 0.31\left(\mathrm{x} 10^{9} / \mathrm{ml}\right)$ with lower values $(\mathrm{P}<0.05)$ observed in white variety. Our values are comparable with Ayorinde (2004) who reported the mean values of sperm concentration in guinea fowl is $3.60 \mathrm{x} 10^{9} / \mathrm{ml}$. Every ejaculate contains few numbers of dead and abnormal spermatozoa which do not interfere with fertility but high proportion of these cells show either impaired fertility or complete sterility (Nalbandov, 1964). Higher dead and morphological abnormal sperm associated with lower sperm concentration in the present study may be the cause of poor fertility $(73.33 \pm 6.15 \%)$ in white variety of guinea fowl when compared with other varieties. Per cent dead and abnormal sperm have been found to be negatively correlated with fertility. Wilson et al. (1969) found that when the number of dead sperm more than $10 \%$, fertility was lowest. A significant decrease in fertility was noticed when only $1 \%$ dead sperm were found.

By employing the A.I. technique, the fertility rates were recorded higher (73-87\%) than natural mated $(55-58 \%)$ in various varieties of guinea fowl (Table 1). Saeki and Nagomi (1964) advocated that AI technique is superior to natural mating in fowl. This seems to be true in guinea fowl. The fertility of guinea fowl eggs ranges from 49 to $58 \%$ in naturally mated stock, while using A.I. results in egg fertility ranging from 70 to $88 \%$ (Galor, 1983; Ayorinde et al., 1989). The low fertility in naturally mated stock may be associated with monogamous sexual behavior of the guinea fowl (Ayeni, 1980; Ayorinde and Okaeme, 1984; Ayorinde, 1987; Nwagu and Alawa, 1995) that cannot be expected to mate frequently and indiscriminately as the male of chicken that is polygamous. Further the male reproductive system of guinea fowl is structurally less efficient than that of chicken (Ayorinde, 2004). In three varieties of guinea fowl, the hatchability on the fertile egg set basis was found ranging 85 to $90 \%$, whereas on total egg set basis ranging from 62-77\% (Table 1). Galor (1983) reported 70-75\% hatchability under artificial incubation. Kabera (1997) noticed $67 \%$ hatchability in guinea fowl. Handling of eggs before incubation and period of storage greatly affect the hatchability of guinea fowl eggs. Nwagu and Alawa (1995) reported that for every day of storage, the hatchability of guinea fowl eggs deteriorated by nearly $4 \%$.

In northern part of India, sexual activity in male guinea fowl begins in the month of March (spring season) with increasing day length and reached to the top in the month of May - June (summer) and decreased sexual intensity drastically in the month of December (winter). Hence, in this study, samples were collected in the month of June (full breeding) and December (non-breeding season). Testicular weight in BS was noticed as 3.74, 4.85 and $4.73 \mathrm{~g}$ in white, pearl and lavender variety which expressed 0.23 , 0.28 , and $0.28 \%$ of body weight respectively (Table 2). Ayorinde (2004) noticed $1.90 \mathrm{~g}$ testes representing only $0.13 \%$ of the body weight. Left testis weight was slightly higher in most of the birds than right. Similar observations were noticed by other workers (Tayler and Gous, 2008; Ali et al., 2015).The basis for testicular asymmetry is still not clear. The overall smaller testes size (1-9 g) may place the guinea fowl at disadvantage when compared with the 14$16 \mathrm{~g}$ (Belshaw, 1985; Nwagu and Alawa, 1995) or 9-30 g per testis weight commonly reported for chicken at sexual maturity which constitute about $1 \%$ of total body weight of the bird (Sturkie and Opel, 1976). Low semen volume in guinea fowl may be due to smaller testicular size.

In all the varieties of guinea fowl a higher body weight associated with nearly 7 to 9 times more testicular weight was noticed in BS than NBS. Similarly, serum testosterone profile was recorded higher $(\mathrm{P}<0.05)$ in $\mathrm{BS}$ than NBS. Plasma testosterone concentration correlated positively with the body weight (Glimore, 1969; Gemmell et al., 1986) and higher testicular weight (Siopes and Wilson, 1975; Mohan et al., 2002; Biswas et al., 2007). Mean values of testosterone in peak breeding season in different varieties were obtained ranged 2.37 to $2.66 \mathrm{ng} / \mathrm{ml}$ which is nearly similar $(2.71 \pm 1.01 \mathrm{ng} / \mathrm{ml})$ as reported by Fukunaga et al. (2012). However, higher values $(5.37 \pm 0.07 \mathrm{ng} / \mathrm{ml})$ were reported by Ali et al. (2015) in full breeding season (summer) with nearly 11 times increase in testes weight in comparison to NBS. The similar pattern of relationship of testes with testosterone in BS and NBS has been revealed by Ali et al. (2015) in guinea fowl and Akbar et al. (2012) in other avian species.

In most avian species, the elevated sexual activity that is recognized as breeding period is influenced by several environmental factors such as day length (photoperiod), temperature, food availability, mates in appropriate physiological condition and suitable breeding habitat (Wingfield et al., 1983). Out of these factors, photo period and temperature has been shown in many cases to be of paramount importance. In view of this, from this study it may be concluded that photoperiod associated with temperature in long days of summer enhance the size of the testes as well as the serum testosterone thereby influenced the physical parameters of semen and high sexual activity in BS. By employing the appropriate approach like extended photoperiod along with suitable temperature, seasonality in guinea fowl can be broken in winter days in order to harvest more number of eggs per year.

\section{ACKNOWLEDGMENTS}

This work was supported by Central Avian Research Institute, Indian Council of Agricultural Research, Ministry of 
Agriculture, Government of India.

\section{CONFLICT OF INTERESTS}

There is no conflict of interests.

\section{AUTHORS' CONTRIBUTION}

Jag Mohan conceived the idea and executed the work. Sanjeev Kumar Sharma provided inputs in statistical data analysis. Gautham Kolluri assisted in seasonal breeding research work. Ram Pratap Singh examined physical characteristics of semen. Jagbir Singh Tyagi helped in fertility studies. Jag Mohan Kataria assisted in preparation of manuscript and providing necessary facilities to carry out this work.

\section{REFERENCES}

-Aire TA, JSO Ayeni JSO, Olowo-Okorun, MO (1983). Some aspects of the reproductive biology of the guinea fowl (Numida meleagris galeatapallas). In: The Helmet Guinea Fowl (Numida meleagris galeatapallas) in Nigeria, Ayeni, J.S.O. (Ed.). Kainji Lake Research Institute, New Bussa, Nigeria. Pp. 189-193.

-Akbar Z, Qureshi AS and Rahman SU (2012). Effects of seasonal variations in different reproductive phases on the cellular response of bursa and testes in Japanese quails (Coturnix japonica). Pak. Vet. J. 32: 525-529.

-Ali MZ, Qureshi MS, Rehan S, Akbar SZ, Manzoor A (2015). Seasonal variations in histomorphology of testes and bursa, immune parameters and serum testosterone concentration in male guinea fowl (Numida meleagris). Pak. Vet. J. 35(1): 88-92.

- Ayeni JSO (1980). The biology and utilization of the helmeted guinea fowl (Numida meleagris galeatapallas) in Nigeria. Ph.D. Thesis, University of Ibadan, Nigeria.

-Ayeni JSO (1983). Studies on grey breasted guinea fowl (Numida meleagris galeatapallas) in Nigeria. World's Poult. Sci. J. 39: 143-51. http://dx.doi.org/10.1079/WPS19830014

-Ayorinde KL and Okaeme AN (1984). All year round guinea fowl-how feasible? West African and food process. March/ April. Pp. 21-22.

-Ayorinde KL (1987). Characteristics and genetic improvement of the grey breasted helmeted guinea fowl (Numida meleagris galeatapallas) in Nigeria for growth and meat production. Ph.D Thesis, University of Ibadan, Ibadan, Nigeria.

-Ayorinde KL (2004). The Spice of Life. The Seventy-First Inaugural Lecture, Thursday, $11^{\text {th }}$ March, 2004, University of Ilorin, Ilorin, Nigeria. Published by the Library and Publications Committee. Pp. 58.

-Ayorinde KL, Ayeni JSO and Oluyemi JA (1989). Laying characteristics and reproductive performance of four indigenous helmeted guinea fowl varieties (Numidia meleagris galeatapallas) in Nigeria. Trop. Agri. 66(3): 277280.

-Belshaw RH (1985). Guinea fowl of the world "world of ornithology". Minirod Book Services, Hampshire, England.

- Biswas A, Divya S, Mandal AB, Majumdar S and Singh R
(2014). Effects of dietary supplementation of organic chromium (picolinate) on physical and biochemical characteristics of semen and carcass traits of male turkeys. Anim. Reprod. Sci. 151(3-4): 237-43. http://dx.doi. org/10.1016/j. anireprosci.2014.10.007

- Biswas ERI (1983). Management of guinea fowl for breeding. In: Ayeni, J.S.O. (Eds.), The Helmet Guinea Fowl (Numida meleagris galeatapallas) in Nigeria. Kainji Lake Research Institute, New Bussa, Nigeria. Pp. 196-197.

- Biswas A, Ranganatha OS, Mohan J, Sastry KV (2007). Relationship of cloacal gland with testes, testosterone and fertility in different lines of male Japanese quail. Anim. Reprod. Sci. 97(1-2): 94-102.

-Bonds H (1997). Alternative farming: A United Nations alternative farming on the Mornington Peninsula. www. independentnewsgroup.com.au/archive/helmi/ (accessed 08.06.2014)

-Burrows WH and Quinn JP (1935). Artificial insemination of chicken and turkeys. Poult. Sci. 14: 251-254. http://dx.doi. org/10.3382/ps.0140251

-Dieng A, Gue'ye EF, Mahoungou-Mouelle, NM and Buldgen A (1999). Effect of diet and poultry species on feed intake and digestibility of nutrients in Senegal. Livestock Res. Rural Dev. 10(3): 5-9.

-Dimitrov SG, Atanasov VK, Surai PF and Denev SA (2007). Effect of organic selenium on turkey semen quality during liquid storage. Anim. Reprod. Sci. 100: 311-317. http:// dx.doi.org/10.1016/j.anireprosci.2006.07.007

-Fisinin VI, Zlochevskaya KV (1989). Guinea fowl. In: Animal Genetic Resources of USSR, FAO Corporate Repository of United Nations, Rome, Italy , Volume 65: 496-504..

- Fukunaga I, Sasalo T, Ando M and Ogawa H (2012). Diurnal variations in plasma testosterone level in the male guinea fowl-chicken hybrids. J. Agri. Sci. 57(2): 115-118.

- Galor (1983). The French Guinea Fowl. Presentation. Service Technique, Galor, Amboise, France. Pp: 15.

- Gemmell, RT, Cepon G and Barnes A (1986). Weekly variations in body weight and plasma testosterone concentrations in the captive male possum, Trichosurus vulpecula. Gen. Comp. Endocrinol. 62(1): 1-7. http://dx.doi.org/10.1016/00166480(86)90087-0

- Glimore DP (1969). Seasonal reproductive periodicity in the male Australian Brush-tailed possum (Trichosurus vulpecula). J. Zool. 157(1): 75-98. http://dx.doi. org/10.1111/j.1469-7998.1969.tb01690.x

-Ikani EI and Dafwang II (2004).The production of guinea fowl in Nigeria. Extension Bulletin No. 207, Poultry Series No. 8. National Agricultural Extension and Research Liaison Services, Zaria, Nigeria. http://www.naerls.gov.ng/extmat/ bulletins/Guinea fowl.pdf. (Accessed 23.05.2011).

- Kaber C (1997). Breeding guinea fowl in Vhumba. Farmer. 67: 16-17.

-Lake PE and Stewart JM (1978). Artificial insemination in poultry. Bull. Min. Agric. Fish. Food. Pp. 213.

- Lake PE (1960). Studies on the dilution and storage of fowl semen.J. Reprod. Fertil.1:30-35.http://dx.doi.org/10.1530/ jrf. 0.0010030

-Mahapatra PS, Mohanty BP, Bisoi PC, Mishra SC, Nayak NR and Mishra MS (1994). Effect of storage on the physical and biochemical parameters of broiler semen. Indian J. Poult. Sci. 29: 146-150.

-Mandal AB, Pathak NN and Singh H (1999). Energy and protein requirements of guinea keets (Numidia meleagris) as 
meat birds in a hot climate. J. Sci. 1: 102-5.

-Mohan J, Moudgal RP, Sastry KVH, Tyagi JS and Singh R (2002). Effects of hemicastration and castration on foam production and its relationship with fertility in male Japanese quail. Theriogenol. 58(1): 29-39. http://dx.doi.org/10.1016/ S0093-691X(02)00863-4

-Mohan J, Singh RP, Sastry KVH, Moudgal RP, Biswas A and Shit N (2011). Influence of chicken native breeds on some physical and biochemical characteristics and short-term storage of semen. Br. Poult. Sci. 52: 395-400. http://dx.doi. org/10.1080/00071668.2011.585145

-Moreki JC, Seabo D (2012). Guinea fowl production in Botswana. J. World's Poult. Res. 2(1): 1-4.

-Moreki JC (2007). Guinea fowl production-A technical guide 1. http://www.gov.bw/global/moa/ guinea $\% 20$ fow $1 \% 20$ production.pdf (Accessed 29.02.2016).

- Nalbandov AV (1964). Reproductive Physiology. W.H. Freeman and Company, San Francisco. Pp: 214.

- Nalubamba KS, Mudenda NB, Bwalya EC, Masuki M,Munyene M and Munang Andu HM (2014). Seasonal variations in health indices of free ranging asymptomatic guinea fowls (Numida meleagris) in Zambia. Asian Pacific J. Trop. Med. 7 (Suppl 1): S143-S149. http://dx.doi.org/10.1016/S19957645(14)60221-2

-Nwagu BI and Alawa CBI (1995). Guinea fowl production I Nigeria. World's Poult. Sci. J. 51: 260-270. http://dx.doi. org/10.1079/WPS19950018

-Nwakalor LN, Okek GC and Njoku DC (1988). Semen characteristics of the guinea fowl Numida meleagris meleagris. Theriogenol. 29: 545-54. http://dx.doi.org/10.1016/S0093691X(88)80003-7

-Pal SK, Somgj H, Saxena VK and Sajjanar CM (1999). Studies on AI in guinea fowl and interspecies hybrid. Indian J. Poult. Sci. 34: 240-242.

- Peters A, Denk AG, Delhey K and Kempenaers B (2004). Carotenoid-based bill colour as an indicator of immunocompetence and sperm performance in male mallards. J. Evol. Biol. 17: 1111-1120. http://dx.doi. org/10.1111/j.1420-9101.2004.00743.x

- Saeki Y and Nagomi Y (1964). Seasonal differences in fertility and hatchability of eggs produced by the natural mating and artificial insemination methods of chickens. Jpn. J. Anim. Reprod.10: 37-43.http://dx.doi.org/10.1262/jrd1955.10.37

-Sayila A (2009). Guinea fowl farming becomes popular in Botswana. World Poultry, 25(10): 30-31.

-Sexton TJA (1977). New poultry semen extender 1. Effect of extension on the fertility of chicken semen. Poult. Sci. 56: 1443-1446. http://dx.doi.org/10.3382/ps.0561443

-Siopes TD and Wilson WO (1975). The cloacal gland and external indicator of testicular development in coturnix. Poult. Sci. 54: 1225-1229. http://dx.doi.org/10.3382/ ps.0541225

-Sturkie PD and Opel H (1976). Reproduction in the male, fertilization, and early embryonic development. In: P.D. Sturkie (Eds.), avian reproduction. Springer-Verlag, New York, USA Pp. 331-347. http://dx.doi.org/10.1007/978-3642-96274-5_17

-Thurston RJ (1995). Storage of poultry semen above freezing for 24-48 hours proceedings of the first international symposium on artificial insemination in poultry, in: Bakst, M.R., Cecil, H. (Eds.), Poultry Science Association, Savoy, IL. Pp. 107-122.

- Tyler NC and Gous RM (2008). The effect of constant photoperiod on testis weight and the use of comb area to predict testis weights in broiler breeders males. S. Afr. J. Anim. Sci. 38: 153-158.

-Wheeler NC and Andrews FC (1943). The influence of season on semen production in domestic fowl. Poult. Sci. 22: 361367. http://dx.doi.org/10.3382/ps.0220361

-Wilson HR, Warnick AC and Gutierrez JH (1969). Differentiation of live from dead sperm in cock semen. Poult. Sci. 48: 714-717. http://dx.doi.org/10.3382/ps.0480714

-Wingfield JC, Moore MC and Farner DS (1983). Endocrine responses to inclement weather in naturally breeding populations of White-crowned Sparrows (Zonotrichia leucophrys pugetensis).The Auk. 100: 56-62.

-Zaniboni L and Cerolini S (2009). Liquid storage of turkey semen: changes in quality parameters, lipid composition and susceptibility to induced in vitro peroxidation in control, n-3 fatty acids and alpha-tocopherol rich spermatozoa. Anim. Reprod. Sci. 112(1-2): 51-65. http://dx.doi.org/10.1016/j. anireprosci.2008.04.002 